\title{
Correction to: Expanding the potential genes of inborn errors of immunity through protein interactions
}

\author{
Humza A. Khan ${ }^{1,2}$ and Manish J. Butte ${ }^{1,2^{*}}$

\section{Correction to: BMC Genomics 22, 618 (2021) https://doi.org/10.1186/s12864-021-07909-3}

Following publication of the original article [1], it was reported that due to a typesetting error that the figure labels in the horizontal axes overlaid a previous version in Fig. 3 and that the Additional files 18 were incorrectly uploaded in CSV format instead of XSLX.

The correct versions of Fig. 3 and the Additional files are included in this Correction article and the original article has been corrected.

Additional file 7: Table S7. IEl Candidate Genes with Average in NK Cells > 1 TPM Filter.

Additional file 8: Table S8. IEl Candidate Genes with Average in T Cells $>1$ TPM Filter.

Published online: 15 October 2021

\section{Reference}

1. Khan HA, Butte MJ. Expanding the potential genes of inborn errors of immunity through protein interactions. BMC Genomics. 2021;22(1):618. https://doi.org/10.1186/s12864-021-07909-3.

\section{Supplementary Information}

The online version contains supplementary material available at https://doi. org/10.1186/s12864-021-08013-2.

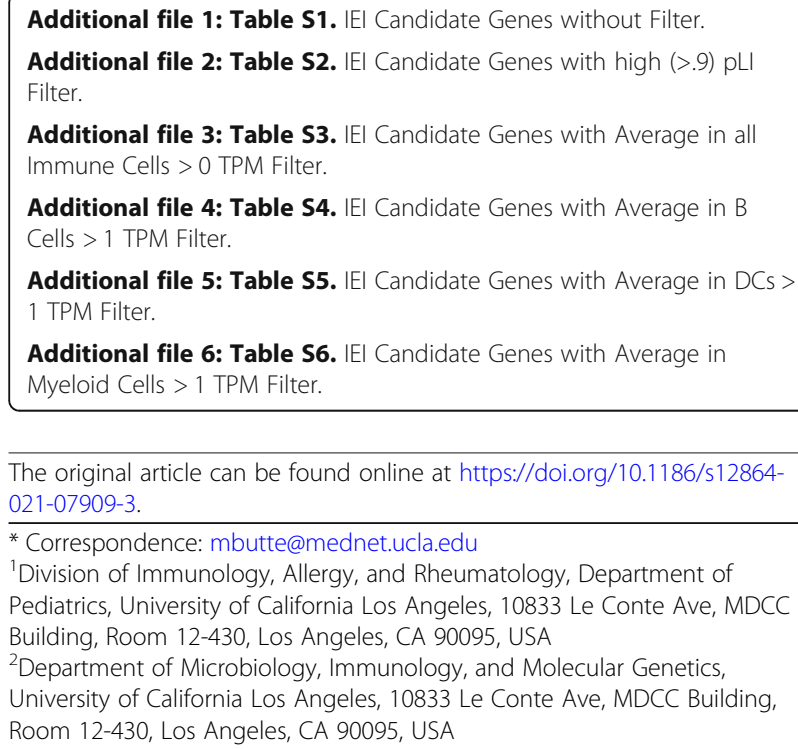

The original article can be found online at https://doi.org/10.1186/s12864021-07909-3.

* Correspondence: mbutte@mednet.ucla.edu

'Division of Immunology, Allergy, and Rheumatology, Department of Pediatrics, University of California Los Angeles, 10833 Le Conte Ave, MDCC Building, Room 12-430, Los Angeles, CA 90095, USA

2Department of Microbiology, Immunology, and Molecular Genetics, University of California Los Angeles, 10833 Le Conte Ave, MDCC Building, Room 12-430, Los Angeles, CA 90095, USA

C The Author(s). 2021 Open Access This article is licensed under a Creative Commons Attribution 4.0 International License, which permits use, sharing, adaptation, distribution and reproduction in any medium or format, as long as you give appropriate credit to the original author(s) and the source, provide a link to the Creative Commons licence, and indicate if changes were made. The images or other third party material in this article are included in the article's Creative Commons licence, unless indicated otherwise in a credit line to the material. If material is not included in the article's Creative Commons licence and your intended use is not permitted by statutory regulation or exceeds the permitted use, you will need to obtain permission directly from the copyright holder. To view a copy of this licence, visit http://creativecommons.org/licenses/by/4.0/. The Creative Commons Public Domain Dedication waiver (http://creativecommons.org/publicdomain/zero/1.0/) applies to the data made available in this article, unless otherwise stated in a credit line to the data. 


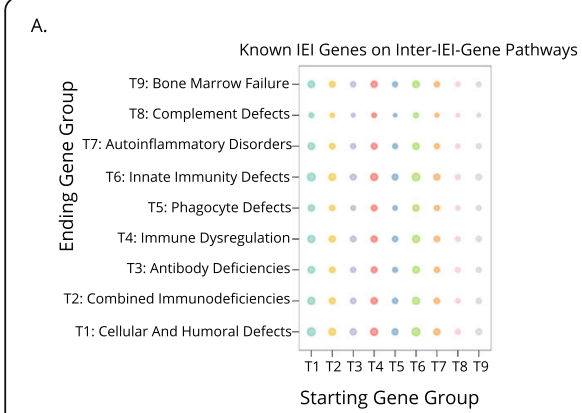

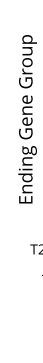

C.

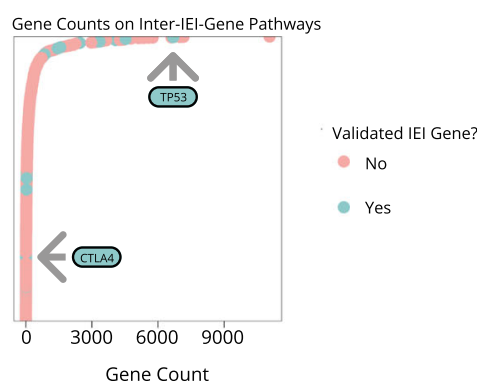

Fig. 3 Discovery Pathway 2 uses protein interaction data to describe pathways between genes. A Bubble plot showing the relative numbers of known IEI genes that lie on protein interaction pathways between known IEI genes and known IEI genes. B Bubble plot showing the relative numbers of candidate IEl genes that lie on protein interaction pathways between known IEI genes and known IEl genes. C Number of times that a particular gene appears along different pathways between known IEl genes and known IEl genes. Two previously known IEl-causative genes are indicated 